\title{
Assessment of clay materials for suitability in drilling mud formulation from part of Ondo State, South-West Nigeria
}

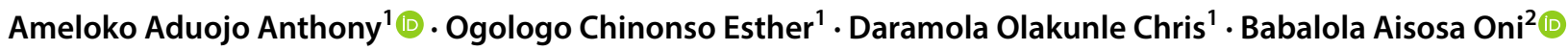

Received: 6 May 2020 / Accepted: 24 June 2020 / Published online: 3 July 2020

(c) The Author(s) 2020

\begin{abstract}
Bentonite used for drilling operations in the oil and gas industry in Nigeria is mainly imported into the country. This project evaluated the efficiency of additives and their function in enhancing the rheological and flow properties of local bentonite clay, obtained from Ibule-soro in Ondo State, Nigeria. X-Ray diffraction analysis of clay samples from previous research around the study area indicated large amount of silica, alumina, and iron contents suggesting that the clays were kaolinite in nature. The clay samples were analyzed for their rheological properties and subsequently compared with the imported bentonite with American Petroleum Institute (API) specifications as standard. The results obtained showed that the local bentonite exhibited low viscosity and high filtration loss. Therefore, to enhance the quality of the clay, it was beneficiated with sodium carbonate $\left(\mathrm{Na}_{2} \mathrm{CO}_{3}\right)$ and carboxymethyl cellulose (CMC). Seven different formulations were made: (20 $\mathrm{g}$ of Imported bentonite), (20 g of local Bentonite Clay), (20 g of local Bentonite Clay $+3.3 \mathrm{~g}$ of $\mathrm{Na}_{2} \mathrm{CO}_{3}+10 \mathrm{~g}$ of CMC), $(25 \mathrm{~g}$ of local Bentonite Clay $+4.2 \mathrm{~g}$ of $\mathrm{Na}_{2} \mathrm{CO}_{3}+10 \mathrm{~g}$ of CMC), $\left(30 \mathrm{~g}\right.$ of local Bentonite Clay $+5.0 \mathrm{~g}$ of $\mathrm{Na}_{2} \mathrm{CO}_{3}+10 \mathrm{~g}$ of CMC), ( $35 \mathrm{~g}$ of local Bentonite Clay $+5.8 \mathrm{~g}$ of $\mathrm{Na}_{2} \mathrm{CO}_{3}+10 \mathrm{~g}$ of CMC), and ( $40 \mathrm{~g}$ of local Bentonite Clay $+6.7 \mathrm{~g}$ of $\mathrm{Na}_{2} \mathrm{CO}_{3}+10 \mathrm{~g}$ of $\mathrm{CMC}$ ). The addition of additives $\left(\mathrm{CMC}\right.$ and $\left.\mathrm{Na}_{2} \mathrm{CO}_{3}\right)$ reduced the calcium content via the cation exchange process and enhanced the rheological properties of the mud samples. The research work revealed that beneficiation of local bentonite with sodium carbonate, the addition of polymer (CMC), and an increase in clay concentration influenced the rheological and flow properties of mud samples. With proper beneficiation of local bentonite in Nigeria, they can be made suitable for drilling operations in the oil and gas industry.
\end{abstract}

Keywords Bentonite $\cdot$ Oil industry $\cdot$ Drilling mud $\cdot$ Beneficiation $\cdot$ Clay

\section{Introduction}

The Nigerian economy is known to be hugely dependent on the oil and gas industry as far as foreign exchange is concern. Over the years, researchers have confirmed that drilling activities performed by oil companies either needed to import either the materials required for the fluids formulation or customized drilling fluid designed to fit the necessities of the Niger Delta formations. The related expense of the import of these materials can amount to millions of dollars per year, causing harm to the country's economy

Ameloko Aduojo Anthony

tonyameloko@yahoo.com

1 Department of Petroleum Engineering, Covenant University, Ota, Nigeria

2 Department of Chemical Engineering, Covenant University, Ota, Nigeria
(Afolabi et al. 2017). The importation of bentonite for drilling of wells in the oil and gas industry has continually diverted huge sum of foreign exchange that could be budgeted for the socioeconomic stability of Nigeria (Dewu et al. 2011). Nigeria bentonite clay has no notable utilization despite its substantial deposits at various locations in the country because of its difficulties being excessive fluid loss and low swelling index (Falode et al. 2007). Due to these difficulties or more, bentonite used in Nigeria for drilling activities is mainly imported into the country (ApoguNwosu et al. 2011). Appropriate measures have not been made regarding the alteration of this clay before it can be utilized in the preparation of drilling mud. It is also vital and proper to enhance the properties of this clay. This particular need has increased the research on the utilization of local clay in the application of drilling fluid in the oil and gas industry. As the interest for bentonite clays rises, there is a need to improve the Nigerian bentonite properties 
to correspond to the API standard (Afolabi et al. 2017). Bentonite is also known as Montmorillonite clay. It is an absorbent aluminum phyllosilicate clay that contains mainly montmorillonite. It was named after the Cretaceous Benton Shale near Rock River, Wyoming, by Wilbur. C. Knight in 1898 (Hosterman and Patterson 1992). Its various types are named after the dominant element, such as calcium (Ca), potassium $(\mathrm{K})$, aluminum $(\mathrm{Al})$, and sodium $(\mathrm{Na})$. There are two major types of bentonite; sodium and calcium bentonite. Most local bentonites are calcium rich, while foreign bentonites are sodium bentonite. In order to be used in an industrial application, such as drilling mud, they must be turned sodic and have a high swelling capacity. In this process, clay is treated with $\mathrm{Na}_{2} \mathrm{CO}_{3}$, causing a double exchange reaction in which the $\mathrm{Ca} 2+$ cations of the clay combine with $\left(\mathrm{CO}_{3}\right)^{2-}$ coming from the sodium carbonate in an aqueous solution, becoming calcium carbonate (Brito et al. 2018). Sodium carboxymethylcellulose (CMC) is primarily a fluid loss reducer but also produces viscosity in freshwater and saline muds whose salt content does not exceed 50,000 mg/L (Bleler et al. 1993). CMC is generally available in a high or low viscosity type. Either grade provides effective fluid loss control (Hughes and Jones 1990). The temperature limit of $\mathrm{CMC}$ is $121^{\circ} \mathrm{C}$, and is not subjected to bacterial degradation (Lummus and Azar 1986). The improvement of bentonite using CMC raises the viscosity, reducing the loss of drilling fluid and maintaining proper flow properties under conditions of moderate temperature, salinity and pressure, providing improvements in the required technological properties (Brito et al. 2018). In stratigraphy and tephrochronology, entirely devitrified (weathered volcanic glass) ash-fall beds are known as potassium bentonite with its dominant clay species being illite. Kaolinite can be intermittently dominant as montmorillonite and illite alternative clay species. Bentonite can be utilized as additives in filtration control and viscosity. Bentonite can be generally obtained from weathered volcanic ash, mainly in the occurrence of water (Magzoub et al. 2017). Sodium montmorillonite are viable bentonite ores which differ broadly in quality and quantity of the swelling clay. Calcium montmorillonites are bentonite ores of less significant value and can be treated to meet API specifications by the addition of some main additives such as sodium carbonate, CMC, starch or polyphosphates, and long chain synthetic polymers. It is, therefore, an essential constituent of drilling fluid as it limits invasion of drilling fluid in the wellbore and prevents mud cake formation (Akintunde 2012). The deposit of bentonite clay cuts across different regions around Nigeria. A couple of regions of the country may have a larger number of deposits than the others. Previous work carried out on Nigerian bentonite indicated that they are low-grade calcium montmorillonite hence the need for beneficiation to improve its quality using sodium salt as part of the process. This project was designed to evaluate the efficiency of additives in enhancing the rheological and flow properties of local bentonite clay, obtained from Ibule-soro in Ondo State, Nigeria. The specific objectives are to;

- Source, process, and characterize the local raw clay.

- Determine the physiochemical properties of the local bentonite material.

- Beneficiate the local bentonite clay with sodium carbonate $\left(\mathrm{Na}_{2} \mathrm{CO}_{3}\right)$ and carboxymethyl cellulose (CMC) to upgrade it to API standard.

- Examine the impact of the stepwise increase in the concentration of the mud and additives on the drilling fluid rheological properties.

\section{Location of study area}

The local bentonite used in this study was obtained from Ibule-Soro town in Ifedore local government area of Ondo State, Southwestern Nigeria (Fig. 1). Its geographical coordinates are longitude $5^{\circ} 7^{\prime} 0^{\prime \prime} \mathrm{E}$ (5.1166667938232), latitude $7^{\circ} 18^{\prime} 0^{\prime \prime} \mathrm{N}(7.3000001907349)$, and elevation of $1,237 \mathrm{ft}$ (377 meters) above sea level. The area is accessible by roads and footpaths, and it occupies about $0.83 \mathrm{~km}^{2}$ in aerial extent. Topographically, the area is characterized by a relatively rugged, undulating topography with outcrops of charnockites, migmatite gneiss with other gneissic rocks as highlands, which range between $600 \mathrm{ft}$ and $1500 \mathrm{ft}$ above sea level. It

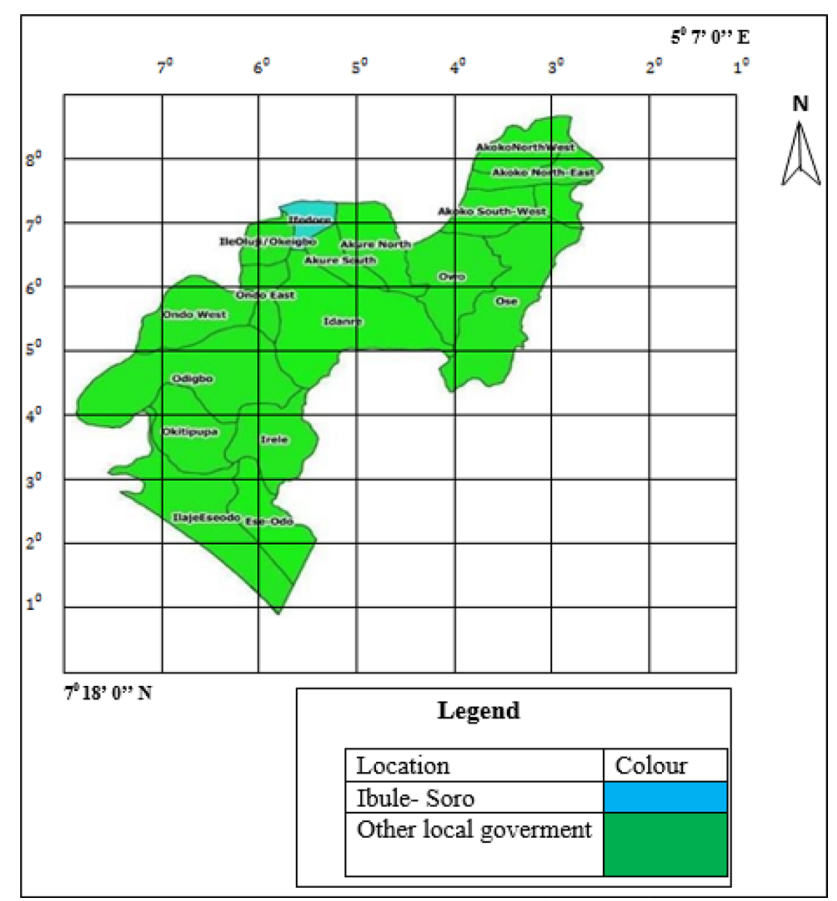

Fig. 1 Map of Ondo State showing location of study area. Modified after Folayan et al. (2016) 


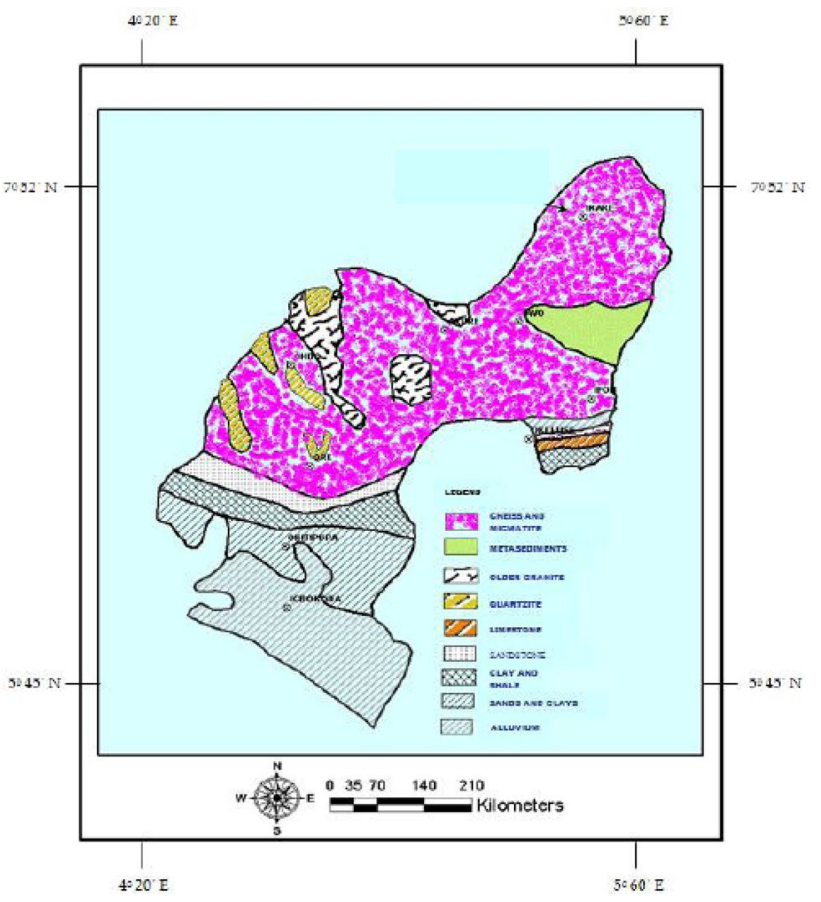

Fig. 2 Geologic map of Ondo State (after Temitope and Opeyemi 2012)

is situated within the Precambrian Basement Complex with the outcrops (Fig. 2), which are predominantly gneiss and migmatite (Temitope and Opeyemi 2012).

\section{Materials and method}

The materials used for this work include;

(i) Raw, non-beneficiated bentonite clay local bentonite clay, obtained from Ibule-soro in Ondo State, Nigeria. Its appearance is whitish/greyish in color.

(ii) Imported/Foreign Bentonite clay used as standard.

(iii) Additives: sodium carbonate $\left(\mathrm{Na}_{2} \mathrm{CO}_{3}\right)$ and carboxymethyl cellulose (CMC).

Quantitative analysis of the chemical compositions of clay materials was carried out by Olubayode et al. (2016) on both processed and unprocessed clay, from Ondo State, Kano State, and some other southwestern States in Nigeria (Table 1 and Fig. 3). This they did with the aid of the laboratory instrument, EDX 3600B Energy Dispersive X-ray Fluorescence (EDXRF) spectrometer. From their results, they observed a large amount of silica, alumina, and iron contents suggesting that the clays were kaolinite in nature and could be used for a variety of purposes.

The clay material used for this study was dried under moderate conditions and was crushed by pounding in
Table 1 Elemental characteristics of clay sample from Ondo State (Olubayode et al. 2016)

\begin{tabular}{|c|c|c|}
\hline S/No & Element & Ondo \\
\hline 1 & $\mathrm{Al}_{2} \mathrm{O}_{3}$ & 40.637 \\
\hline 2 & $\mathrm{SiO}_{2}$ & 45.637 \\
\hline 3 & $\mathrm{P}_{2} \mathrm{O}_{5}$ & 0.117 \\
\hline 4 & $\mathrm{SO}_{3}$ & 0.432 \\
\hline 5 & $\mathrm{~K}_{2} \mathrm{O}$ & 0.406 \\
\hline 6 & $\mathrm{CaO}$ & 0.060 \\
\hline 7 & $\mathrm{TiO}_{2}$ & 0.859 \\
\hline 8 & $\mathrm{MnO}$ & 0.128 \\
\hline 9 & $\mathrm{FeO}$ & 5.956 \\
\hline 10 & $\mathrm{Ni}_{2} \mathrm{O}$ & 0.054 \\
\hline 11 & $\mathrm{CuO}$ & 0.035 \\
\hline 12 & $\mathrm{ZnO}$ & 0.063 \\
\hline 13 & Mo & 0.149 \\
\hline 14 & Loss of ignition & 5.467 \\
\hline
\end{tabular}

a mortar (Fig. 4). Sieve analysis was carried out on the crushed clay with the use of a sieve shaker and setting the working time to $120-130 \mathrm{~s}$ using different mesh sizes from 500 microns mesh to 300 microns mesh to 150 microns mesh to 75 microns mesh to obtain fine particles (Fig. 5). The experimental procedure involved the addition of a calcium bentonite sample to a sodium carbonate aqueous solution to form a bentonite suspension, which was heated and stirred continuously to form sodium bentonite and calcium carbonate. Calcium bentonite is converted to sodium bentonite by combining chemical (addition of sodium carbonate), mechanical (agitation), and thermal (heating) treatment procedures.

The sodium carbonate solution was formulated by dissolving sodium carbonate powder (soda ash) in distilled water. This solution served as a source of carbonate and sodium ions for an ion exchange process with $\mathrm{Ca}$-bentonite, where the calcium can be precipitated as calcium bentonite (Magzoub et al. 2017). The addition of calcium bentonite sample to the already prepared sodium carbonate solution forms a bentonite suspension. The provided $\mathrm{Ca}$-bentonite was treated with $\mathrm{Na}_{2} \mathrm{CO}_{3}$ making use of a sodium carbonate/ bentonite weight ratio of 1:6 by varying the sodium carbonate content and bentonite concentration. For this experiment, five different samples were formulated with varying sodium carbonate/bentonite weight ratio while maintaining a standard measurement of $350 \mathrm{ml}$ of distilled water (standard laboratory barrel). The range of sodium carbonate/bentonite weight ratio is as follows:

(a) $3.3 \mathrm{~g}$ of $\mathrm{Na}_{2} \mathrm{CO}_{3}$ to $20 \mathrm{~g}$ of local calcium bentonite.

(b) $4.2 \mathrm{~g}$ of $\mathrm{Na}_{2} \mathrm{CO}_{3}$ to $25 \mathrm{~g}$ of local calcium bentonite.

(c) $5.0 \mathrm{~g}$ of $\mathrm{Na}_{2} \mathrm{CO}_{3}$ to $30 \mathrm{~g}$ of local calcium bentonite. 
Fig. 3 X-Ray diffraction of selected clays from parts of Nigeria (Olubayode et al. 2016)

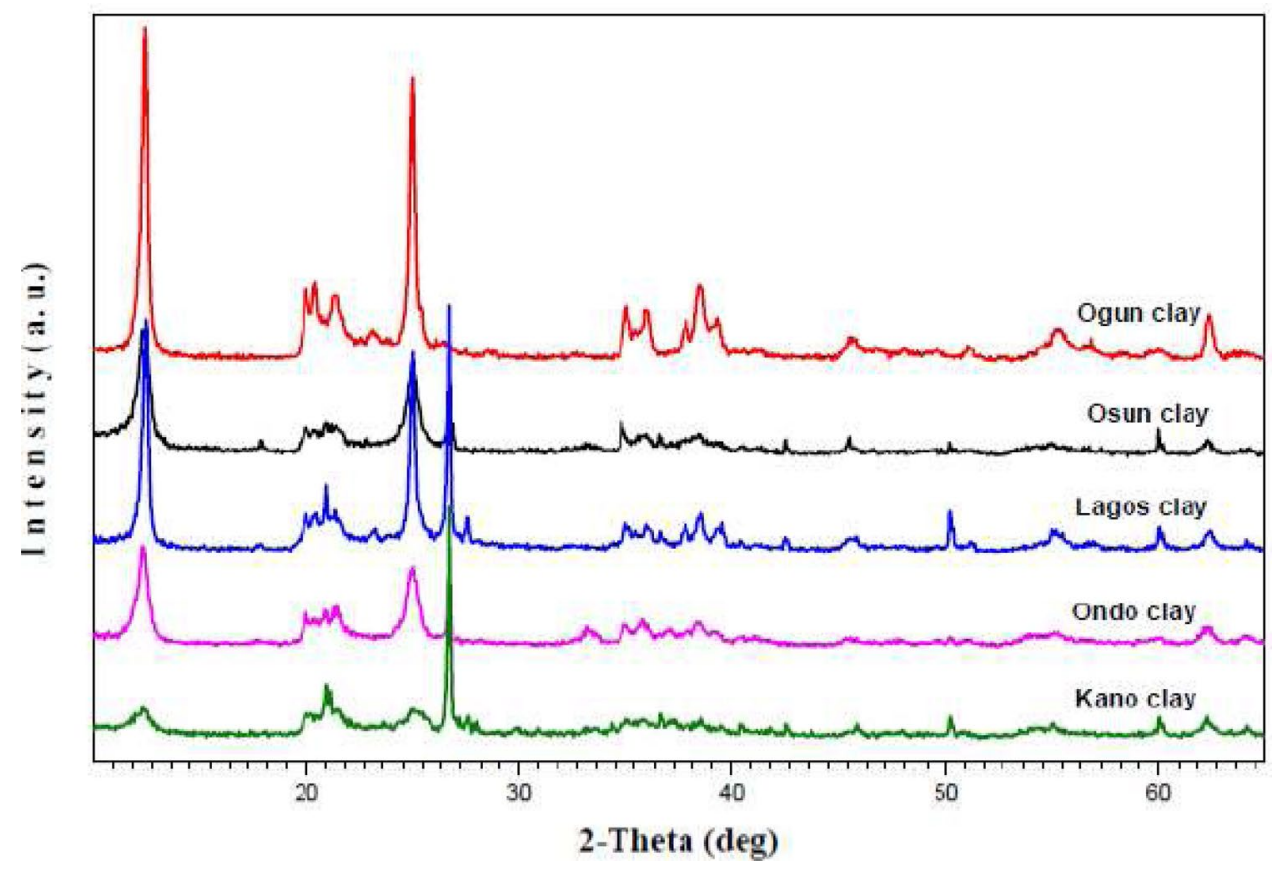

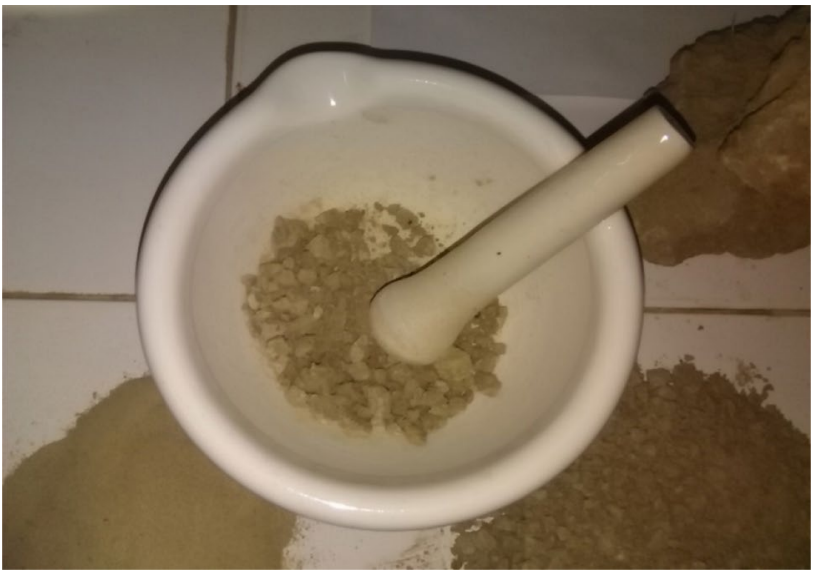

Fig. 4 Mortar and pestle been used to crush clay material

(d) $5.8 \mathrm{~g}$ of $\mathrm{Na}_{2} \mathrm{CO}_{3}$ to $35 \mathrm{~g}$ of local calcium bentonite.

(e) $6.7 \mathrm{~g}$ of $\mathrm{Na}_{2} \mathrm{CO}_{3}$ to $40 \mathrm{~g}$ of local calcium bentonite.

Following the preparation of the bentonite suspension, the bentonite suspension was heated and stirred continuously with the aid of a magnetic stirrer and a magnetic stirrer hot plate (Fig. 6), for $3 \mathrm{~h}$ maintaining a temperature of $70^{\circ} \mathrm{C}$ and a speed of $45 \mathrm{rpm}$ (revolution per time).

The continuous heating and stirring increased the bentonite particle size or platelet, speeds up the swelling process, and caused the expansion of the bentonite platelets for increased swelling and enhanced ion exchange process. It brought about the movement of sodium ions to the surface of the bentonite layer, allowing increased $\mathrm{Na}^{+}$activation and

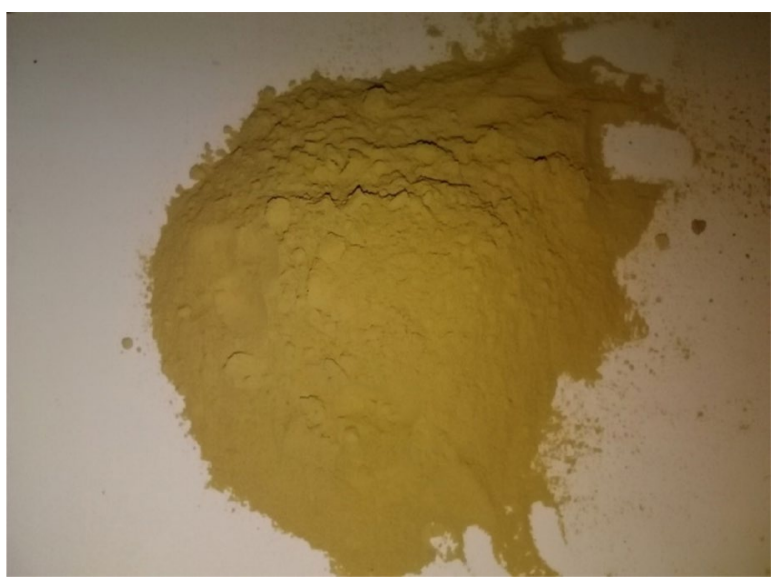

Fig. 5 Crushed clay material

an increase in the $\mathrm{Na} / \mathrm{Ca}$ ratio and further enhanced the rheological properties (Magzoub et al. 2017). After the continuous heating and stirring process, $10 \mathrm{~g}$ of the CMC additive was added to the already heated bentonite suspensions and stirred for $10 \mathrm{~min}$ with the use of a magnetic stirrer to form a bentonite-CMC suspension and to achieve a homogenous dispersion where the polymer chains are well confined by the clay particles. The rheological properties of drilling mud consist of; Plastic viscosity, Apparent viscosity, Yield point, mud density, specific gravity, and alkalinity. The experiment was carried out on the local bentonite, foreign bentonite (as control), and local bentonite with sodium carbonate and CMC (Fig. 7). 


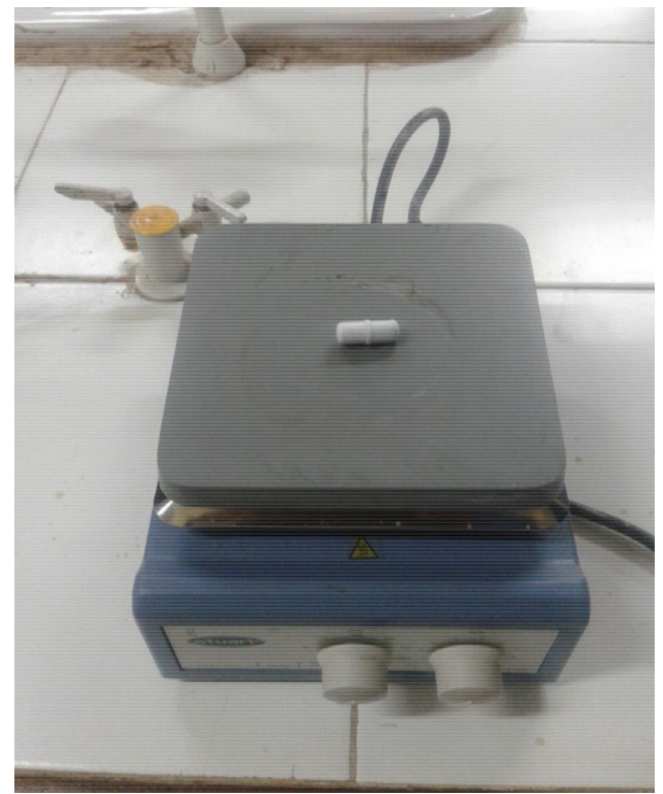

Fig. 6 Magnetic hot plate and stirrer

The main equipment used for this experiment was a Baroid Rotary Viscometer. It is a coaxial viscometer with a set speed of 600 RPM, 300 RPM, 200 RPM, 100 RPM, and 3 RPM (GEL) that can be switch-selectable with the RPM handle. From this experiment, the rheological properties calculated included;

Plastic Viscosity $(\mathrm{cp}), \mathrm{PV}=600$ RPM reading-300 RPM reading

Yield Point $\left(\mathrm{lbs} / 100 \mathrm{ft}^{2}\right), \mathrm{YP}=300 \mathrm{RPM}$ reading-PV

Apparent Viscosity (cp), AV $=\frac{600 \mathrm{RPM} \text { reading }}{2}$

The gel strength was determined at $10 \mathrm{~s}$ after the clay was mixed in the cup and at 10 min after the mud was mixed in the cup. 3 RPM speed in a rotary viscometer was utilized to decide gel strength. The readings recorded from this experiment include;

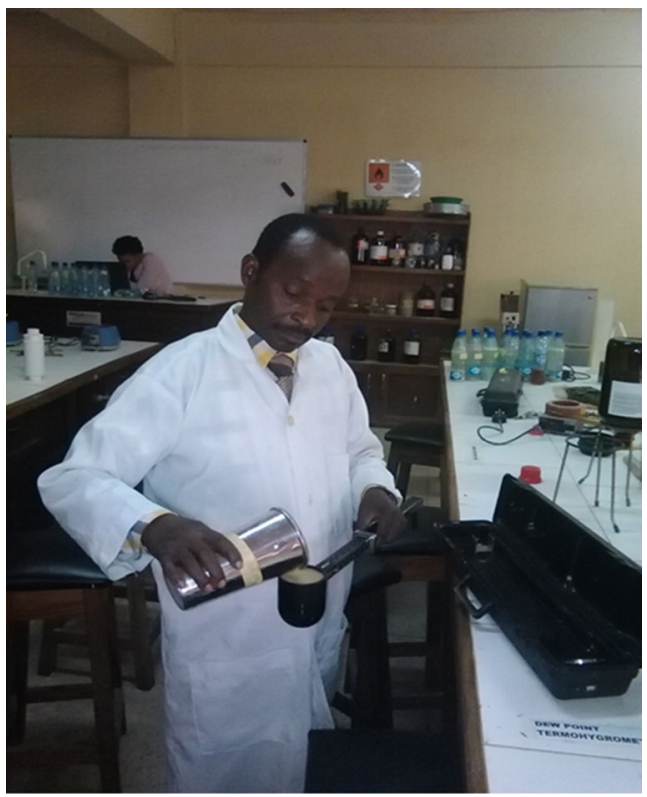

Fig. 7 Density of mud being measured

cap, cell, rubber gasket, and base top) mounted in a frame, filter paper, graduated glass cylinder, and a pressure source (compressed nitrogen cylinder) using a standard cell of 100 psi for $30 \mathrm{~min}$ at room temperature $\left(27^{\circ} \mathrm{C}\right)$. $\mathrm{pH}$ determination indicates the acid or alkaline property of the drilling mud. In drilling fluid, the acidity and alkalinity can be estimated by determining the hydrogen ion concentration. For an aqueous solution, the $\mathrm{pH}$ meter measures the electro potential created amid a particular glass electrode and a reference electrode. This experiment was also carried out on the local bentonite, foreign bentonite, and local bentonite with sodium carbonate and CMC.

\section{Results and discussion}

Table 2 shows the results of the various physiochemical properties measured from the experiment carried out on the imported bentonite. These values were used as standard with which the values obtained from the experiment on

Gel Strength, $10 \mathrm{~s}(\mathrm{lb} / 100 \mathrm{ft} 2)=$ maximum dial deflection after $10 \mathrm{~s}$

Gel Strength, $10 \mathrm{~min}(\mathrm{lb} / 100 \mathrm{ft} 2)=$ maximum dial deflection after $10 \mathrm{~min}$

The experiment for the determination of the filtration properties was also carried out on the local bentonite, foreign bentonite, and local bentonite with sodium carbonate and CMC. The main apparatus utilized for this experiment was a standard filter press comprising of; mud reservoir (top the pure local bentonite and beneficiated local bentonite were benchmarked. The table also shows the results of the physiochemical parameters obtained from the experiment performed on the pure local bentonite. From the results, it was observed that the viscosities at 600 RPM and 300 RPM were extremely low when compared with the values of the 
Table 2 Showing physiochemical properties of $20 \mathrm{~g}$ of imported and local Bentonites

\begin{tabular}{lll}
\hline Measured parameters & $\begin{array}{l}\text { Dial readings } \\
\text { (imported bentonite) }\end{array}$ & $\begin{array}{l}\text { Dial readings } \\
\text { (local benton- } \\
\text { ite) }\end{array}$ \\
\hline Mud density (ppg) & $8.55 \mathrm{ppg}$ & $8.55 \mathrm{ppg}$ \\
Specific gravity & 1.025 & 1.03 (s.g.) \\
$\mathrm{pH}$ & 10.21 & 6.6 \\
Viscosity (cp), 600 RPM & $40 \mathrm{cp}$ & $3 \mathrm{cp}$ \\
Viscosity (cp), 300 RPM & $28 \mathrm{cp}$ & $2.5 \mathrm{cp}$ \\
Plastic viscosity (cp) & $12 \mathrm{cp}$ & $0.5 \mathrm{cp}$ \\
Apparent viscosity (cp) & $20 \mathrm{cp}$ & $1.5 \mathrm{cp}$ \\
Yield point (lb/100 ft $\left.{ }^{2}\right)$ & $16 \mathrm{lb} / 100 \mathrm{ft}^{2}$ & $2 \mathrm{lb} / 100 \mathrm{ft}^{2}$ \\
Gel strength, $10 \mathrm{~s}$ & $3.5 \mathrm{~s}$ & $2 \mathrm{~s}$ \\
Gel strength, $10 \mathrm{~min}$ & $6.5 \mathrm{~min}$ & $1.5 \mathrm{~min}$ \\
Fluid loss (ml) at $30 \mathrm{~min}$ & $11 \mathrm{ml}$ & $119.4 \mathrm{ml}$ \\
\hline
\end{tabular}

standard bentonite. The other rheological properties (plastic viscosity, apparent viscosity, gel strength and, yield point) were also found to be extremely low when compared with the foreign bentonite. Also worthy of note was the very high fluid loss value obtained from the filtration test performed on the local bentonite clay.

Tables 3 and 4 show the result of the rheological parameters of the mud when varied quantity of the pure bentonites $(20 \mathrm{~g}, 25 \mathrm{~g}, 30 \mathrm{~g}, 35 \mathrm{~g}$, and $40 \mathrm{~g})$ were beneficiated with $10 \mathrm{~g}$ of CMC (polymer) and different concentrations of $\mathrm{Na}_{2} \mathrm{CO}_{3}(3.3 \mathrm{~g}, 4.2 \mathrm{~g}, 5.0 \mathrm{~g}, 5.8 \mathrm{~g}$, and $6.7 \mathrm{~g}$ respectively). The volume of the local bentonite and salt concentration was varied to examine their effect on the rheological properties of the mud, and also to investigate the effect of polymer (CMC) on different concentrations of the local bentonite. From the results, the rheological properties of the beneficiated local bentonite were slightly improved. From Table 3, it was observed that out of the five samples, the

Table 3 Showing physiochemical properties of treated mud

\begin{tabular}{|c|c|c|c|}
\hline Sample (treated bentonite) & $\begin{array}{l}\text { Dial readings } \\
20 \mathrm{~g} \text { of local bentonite clay }+3.3 \mathrm{~g} \text { of } \\
\mathrm{Na}_{2} \mathrm{CO}_{3}+10 \mathrm{~g} \text { of } \mathrm{CMC}\end{array}$ & $\begin{array}{l}\text { Dial readings } \\
25 \mathrm{~g} \text { of local bentonite clay }+4.2 \mathrm{~g} \text { of } \\
\mathrm{Na}_{2} \mathrm{CO}_{3}+10 \mathrm{~g} \text { of } \mathrm{CMC}\end{array}$ & $\begin{array}{l}\text { Dial readings } \\
30 \mathrm{~g} \text { of local bentonite } \\
\text { clay }+5.0 \mathrm{~g} \text { of } \mathrm{Na}_{2} \mathrm{CO}_{3}+10 \mathrm{~g} \\
\text { of } \mathrm{CMC}\end{array}$ \\
\hline Mud density (ppg) & $8.6 \mathrm{ppg}$ & $8.71 \mathrm{ppg}$ & $8.75 \mathrm{ppg}$ \\
\hline Specific gravity (s.g.) & 1.03 (s.g.) & 1.045 (s.g.) & 1.045 (s.g.) \\
\hline $\mathrm{Ph}$ & 10.73 & 10.89 & 10.90 \\
\hline Viscosity (cp), 600 RPM & $5 \mathrm{cp}$ & $5.5 \mathrm{cp}$ & $6 \mathrm{cp}$ \\
\hline Viscosity (cp), 300 RPM & $3.5 \mathrm{cp}$ & $4 \mathrm{cp}$ & $4 \mathrm{cp}$ \\
\hline Plastic viscosity $(\mathrm{cp})$ & $1.5 \mathrm{cp}$ & $1.5 \mathrm{cp}$ & $2 \mathrm{cp}$ \\
\hline Apparent viscosity (cp) & $2.5 \mathrm{cp}$ & $2.75 \mathrm{cp}$ & $3 \mathrm{cp}$ \\
\hline Yield point $\left(\mathrm{lb} / 100 \mathrm{ft}^{2}\right)$ & $2 \mathrm{lb} / 100 \mathrm{ft}^{2}$ & $2.5 \mathrm{lb} / 100 \mathrm{ft}^{2}$ & $2 \mathrm{lb} / 100 \mathrm{ft}^{2}$ \\
\hline Gel strength, $10 \mathrm{~s}$ & $2 \mathrm{~s}$ & $1.5 \mathrm{~s}$ & $1.5 \mathrm{~s}$ \\
\hline Gel strength, $10 \mathrm{~min}$ & $2 \min$ & $1.5 \mathrm{~min}$ & $1.5 \mathrm{~min}$ \\
\hline Fluid loss $(\mathrm{ml})$ at $30 \mathrm{~min}$ & $49 \mathrm{ml}$ & $48.5 \mathrm{ml}$ & $47 \mathrm{ml}$ \\
\hline
\end{tabular}

Table 4 Showing physiochemical properties of treated mud

\begin{tabular}{lll}
\hline Sample (treated bentonite) & $\begin{array}{l}\text { Dial readings } \\
35 \mathrm{~g} \text { of local bentonite clay }+5.8 \mathrm{~g} \text { of } \\
\mathrm{Na}_{2} \mathrm{CO}_{3}+10 \mathrm{~g} \text { of CMC }\end{array}$ & $\begin{array}{l}\text { Dial readings } \\
40 \mathrm{~g} \text { of local bentonite } \\
\text { clay }+6.7 \mathrm{~g}_{\text {of }} \mathrm{Na}_{2} \mathrm{CO}_{3}+10 \mathrm{~g} \\
\text { of CMC }\end{array}$ \\
\hline Mud density (ppg) & $8.78 \mathrm{ppg}$ & $8.95 \mathrm{ppg}$ \\
Specific gravity (s.g.) & $1.05(\mathrm{s.g})$. & 1.075 (s.g.) \\
pH & 10.92 & 10.93 \\
Viscosity (cp), 600RPM & $6.5 \mathrm{cp}$ & $7 \mathrm{cp}$ \\
Viscosity (cp), 300RPM & $4.5 \mathrm{cp}$ & $5 \mathrm{cp}$ \\
Plastic viscosity (cp) & $2 \mathrm{cp}$ & $2 \mathrm{cp}$ \\
Apparent viscosity (cp) & $3.25 \mathrm{cp}$ & $3.5 \mathrm{cp}$ \\
Yield point (lb/100 ft $\left.{ }^{2}\right)$ & $2.5 \mathrm{lb} / 100 \mathrm{ft}^{2}$ & $3 \mathrm{lb} / 100 \mathrm{ft}^{2}$ \\
Gel strength, $10 \mathrm{~s}$ & $2 \mathrm{~s}$ & $1.0 \mathrm{~s}$ \\
Gel strength, $10 \mathrm{~min}$ & $2 \mathrm{~min}$ & $1.5 \mathrm{~min}$ \\
Fluid loss (ml) at $30 \mathrm{~min}$ & $45 \mathrm{ml}$ & $41.5 \mathrm{ml}$ \\
\hline
\end{tabular}


mud had the least improvement in its rheological properties when the local bentonite $(20 \mathrm{~g}+350 \mathrm{ml}$ of distilled water) was beneficiated with $3.3 \mathrm{~g}$ of $\mathrm{Na}_{2} \mathrm{CO}_{3}$ and $10 \mathrm{~g}$ of CMC. Gradual enhancement of the rheological properties of the samples was observed as the volume of the local bentonite, and salt concentration increased. Also, it was observed from Tables 3 and 4 that the filtration loss of the beneficiated samples reduced significantly when compared with the unbeneficiated local bentonite (Table 2). Table 4 showed the best improvement in terms of filtration loss $(41.5 \mathrm{ml})$ when $40 \mathrm{~g}$ of mud was beneficiated using $350 \mathrm{ml}$ of distilled water, $6.7 \mathrm{~g}$ of $\mathrm{Na}_{2} \mathrm{CO}_{3}$, and $10 \mathrm{~g}$ of CMC.

The presence of CMC in the samples assisted the reduction in filtrate loss. The plastic viscosity, yield point, apparent viscosity values of the different mud samples depended on the $600 \mathrm{rpm}$ and $300 \mathrm{rpm}$ readings. And these viscosity values were influenced by the addition of CMC to the mud samples. The increase in the volume of bentonite concentration leads to a greater influence of CMC on the mud samples viscosity. The beneficiation of local bentonite with soda ash led to the improvement of the swelling clay capacity, the ability of the clay particles to flocculate, bringing about enhanced mudflow properties. The improvement of the treated bentonite can be attributed to some reasons. First and foremost, the difference in mineralogy influenced by the depositional environment can influence the mud properties (Omole et al. 2013). Secondly, the use of the heating (thermal) and stirring (agitation) treatment procedure can also improve the properties of the clay as this procedure results in an increase in bentonite particle size or platelet, enhances the conversion of calcium-based bentonite to sodium-based bentonite, increase in $\mathrm{Na}^{+} / \mathrm{Ca}^{2+}$ ratio and allow $\mathrm{Na}^{+}$activation and swelling. Thirdly, the conversion of calcium smectite to sodium smectite enlarges the space among the particles of the clay. $\mathrm{Na}^{+}$is known to be a monovalent cation and can combine to a charge deficient area and can create separated sheets when dispersed in water unlike $\mathrm{Ca}^{2+}$ which is a divalent cation that cannot combine to two negative charges but focuses on one sheet and hence combines two sheets together. Fourthly, the improvement of mud properties can be as a result of their free swell volume and proved by their physiochemical properties in terms of cation exchange ability, expandable and nonexpandable minerals (Magzoub et al. 2017).

A high mud density manages the formation pressure and improves the stability of the wellbore. Figure $8 \mathrm{a}$ is a histogram plot showing the comparison between the densities of the standard bentonite, local bentonite, and the five different test samples. The different dial readings were compared with that of the imported bentonite, and it was observed that there was a progressive rise in the densities of the mud samples. The addition of a viscosifier to a mud sample can lead to an increase in the mud density. An increase in mud density was greatly influenced by adding carboxymethyl cellulose (CMC) to the different samples. Increase in the volume of the bentonite resulted in a higher effect of $\mathrm{CMC}$ on the mud samples increasing the mud density of the samples.

Specific gravity defines the density or weight of fluid compared to the density of an equal volume of water at a specified temperature. Figure $8 \mathrm{~b}$ is a plot showing the comparison between the specific gravity of the imported bentonite, local bentonite, and the five samples. The different dial readings were compared with the standard bentonite, and it was observed that there was also an increase in the specific gravity of the different samples. The increase in the specific gravity of samples was influenced by the addition of CMC to the five samples at different concentrations of bentonite and sodium carbonate.

$\mathrm{pH}$ is a measure of the concentration of hydrogen ions in aqueous solution. If the water used in the preparation of a drilling mud is too hard or the $\mathrm{pH}$ value is not within the range of 8.5-9.5, then the mud will take a longer period to hydrate, or it might not hydrate fully. Figure 9a shows a histogram plot comparing the $\mathrm{pH}$ of the imported bentonite, local bentonite, and the five different samples. A critical look at the plot indicated an increase in the $\mathrm{pH}$ of the mud samples. This increase occurred as a result of the beneficiation of the mud samples by the addition of sodium carbonate $\left(\mathrm{Na}_{2} \mathrm{CO}_{3}\right)$. Sodium carbonate is alkaline in nature, as it is a strong base. The higher the bentonite and sodium carbonate concentrations, the higher the $\mathrm{pH}$ values of the mud samples. The conversion of calcium carbonate to sodium carbonate through ion exchange can also influence the $\mathrm{pH}$ of the mud samples.

A mud viscosity illustrates the amount of resistance of the fluid to shear stress. The viscosity of the drilling fluid can be improved upon by treatment with polymers such as CMC. Figure $9 \mathrm{~b}$ shows the comparison between the viscosities at $600 \mathrm{rpm}$ of the imported bentonite, local bentonite, and the five different samples. From the chart, it was observed that there were generally poor values of viscosity when compared with the standard mud sample. However, with beneficiation, there was an improvement in the viscosity of the treated mud samples when compared with the untreated local bentonite. CMC is suitable for increasing viscosity of the clay suspension and stabilizing the clay suspension. The higher the bentonite concentration, the higher the polymer (CMC) effect on the viscosity of the mud samples. From the result, the most improved viscosity was observed in sample five ( $40 \mathrm{~g}$ of bentonite $+6.7 \mathrm{~g}$ of $\mathrm{Na}_{2} \mathrm{CO}_{3}+10 \mathrm{~g}$ of CMC) having the highest concentration of bentonite.

Figure 10a shows the comparison between the viscosities at $300 \mathrm{rpm}$ of the imported bentonite, local bentonite, and the five different samples. The viscosity of the beneficiated clay was also low relative to the standard bentonite. The addition of CMC to the different mud samples led to a slight increase in the viscosity of the treated local samples compared to the untreated local bentonite. From the chart, sample five ( $40 \mathrm{~g}$ of local bentonite $+6.7 \mathrm{~g}$ of $\mathrm{Na}_{2} \mathrm{CO}_{3}+10 \mathrm{~g}$ of $\mathrm{CMC}$ ) had the most improved viscosity at $300 \mathrm{rpm}$. The higher the bentonite 


\section{MUD DENSITY (PPG)}

- Imported Bentonite

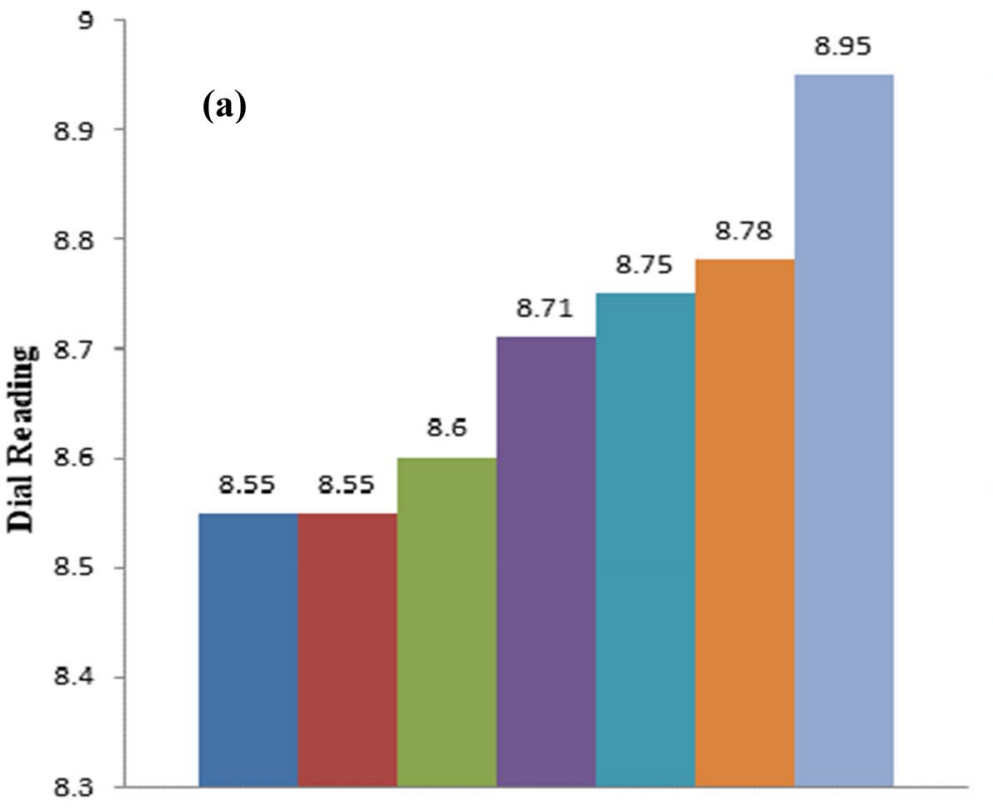

Mud density (PPG)

SPECIFIC GRAVITY

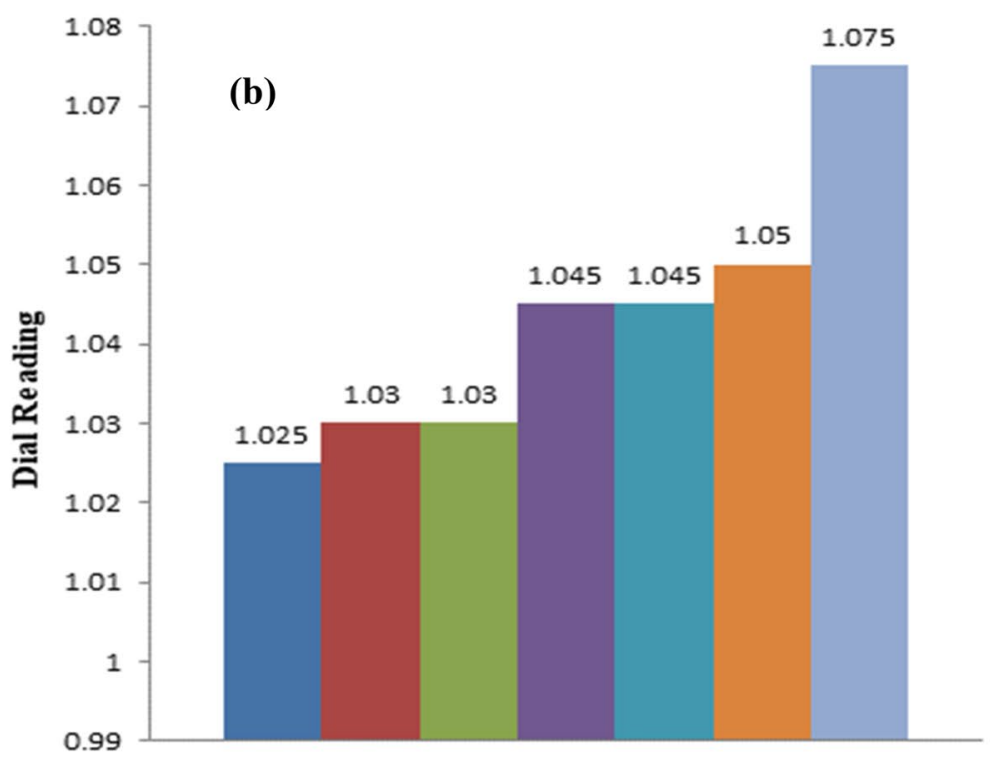

Specific gravity
E Local Bentonite

20g of Local Bentonite Clay $+3.3 \mathrm{~g}$ of $\mathrm{Na} 2 \mathrm{CO} 3+10 \mathrm{~g}$ of $\mathrm{CMC}$

a $25 \mathrm{~g}$ of Local Bentonite Clay $+4.2 \mathrm{~g}$ of $\mathrm{Na} 2 \mathrm{CO} 3+10 \mathrm{~g}$ of $\mathrm{CMC}$

2

al $30 \mathrm{~g}$ of Local Bentonite Clay $+5.0 \mathrm{~g}$ of $\mathrm{Na} 2 \mathrm{CO}+10 \mathrm{~g}$ of $\mathrm{CMC}$

3

= $35 \mathrm{~g}$ of Local Bentonite Clay $+5.8 \mathrm{~g}$ of $\mathrm{Na2} \mathrm{CO} 3+10 \mathrm{~g}$ of $\mathrm{CMC}$

$40 \mathrm{~g}$ of Local Bentonite Clay $+6.7 \mathrm{~g}$ of $\mathrm{Na} 2 \mathrm{CO} 3+10 \mathrm{~g}$ of $\mathrm{CMC}$

5

n Imported Bentonite

- Local Bentonite

= $20 \mathrm{~g}$ of Local Bentonite Clay $+3.3 \mathrm{~g}$ of $\mathrm{Na} 2 \mathrm{CO}+10 \mathrm{~g}$ of $\mathrm{CMC}$

- $25 \mathrm{~g}$ of Local Bentonite Clay $+4.2 \mathrm{~g}$ of $\mathrm{Na} 2 \mathrm{CO}+10 \mathrm{~g}$ of $\mathrm{CMC}$

I $30 \mathrm{~g}$ of Local Bentonite Clay $+5.0 \mathrm{~g}$ of $\mathrm{Na} 2 \mathrm{CO} 3+10 \mathrm{~g}$ of $\mathrm{CMC}$

$35 \mathrm{~g}$ of Local Bentonite Clay $+5.8 \mathrm{~g}$ of $\mathrm{Na} 2 \mathrm{CO} 3+10 \mathrm{~g}$ of $\mathrm{CMC}$

$=40 \mathrm{~g}$ of Local Bentonite Clay $+6.7 \mathrm{~g}$ of $\mathrm{Na} 2 \mathrm{CO} 3+10 \mathrm{~g}$ of $\mathrm{CMC}$

5

Fig. 8 Histogram showing Mud density (a) and specific gravity (b) of samples

concentration, the greater the polymer (CMC) effect on the viscosity of the mud samples. The result also revealed higher viscosity of the mud at $600 \mathrm{rpm}$ when compared with the values obtained at $300 \mathrm{rpm}$. The resistance of the flow of fluids due to mechanical friction in the drilling mud, such as the shape and size of solid, concentration of solid, viscosity of the fluid phase in the continuous phase is known as Plastic viscosity. Figure $10 \mathrm{~b}$ shows the comparison between the plastic viscosities of the standard bentonite, local bentonite, and the five different samples. The values used for the plot was obtained from the 

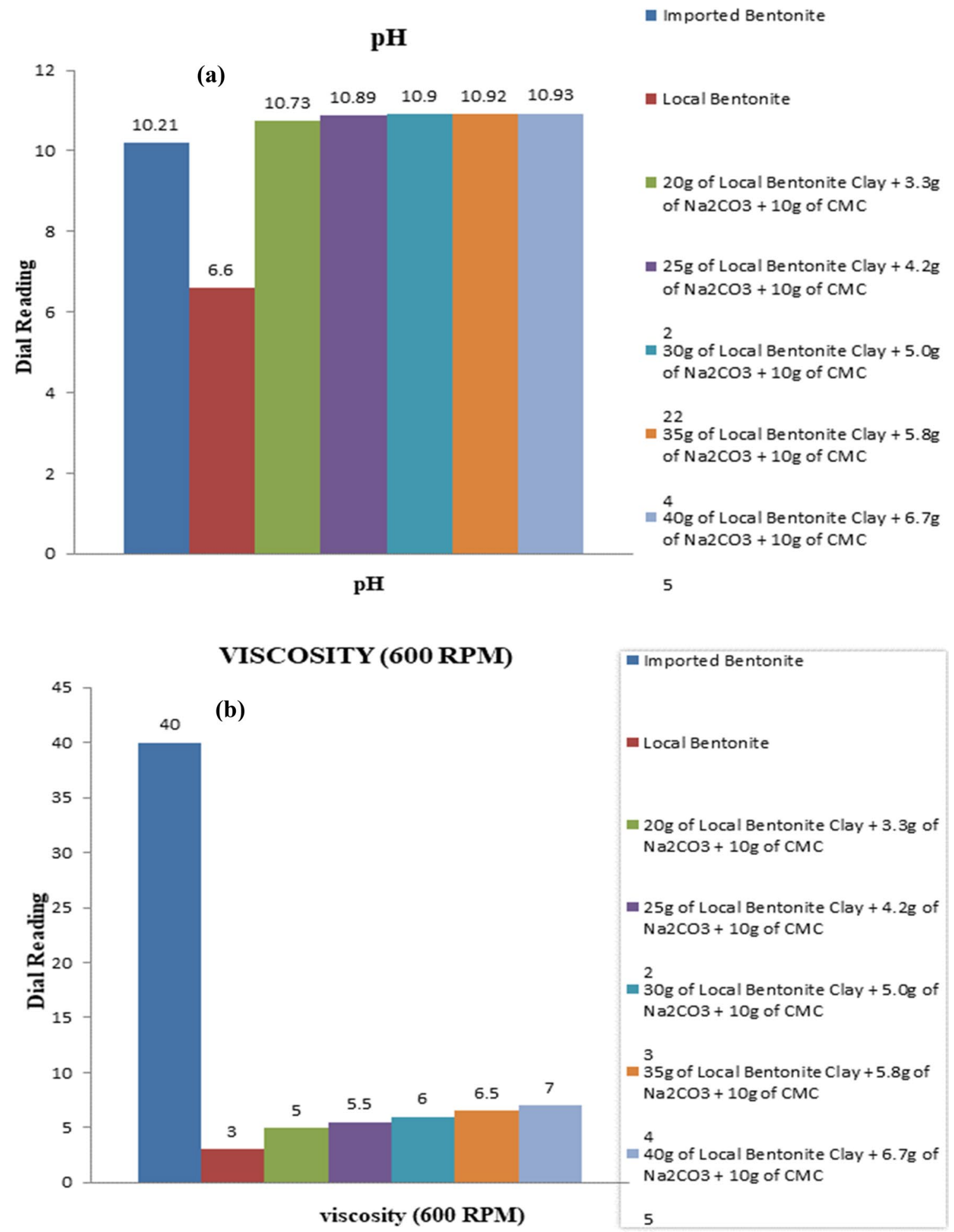

Fig. 9 Histogram showing the $\mathrm{pH}$ (a) and Viscosity at $600 \mathrm{RPM}(\mathbf{b})$ of samples

difference between measurements at $600 \mathrm{rpm}$ and measurements at $300 \mathrm{rpm}$. The plastic viscosity was relatively low when compared with the standard, and no significant improvement was observed with an increase in the concentration of $\mathrm{Na}_{2} \mathrm{CO}_{3}$ and $\mathrm{CMC}$. The measure of the viscosity of a fluid at a given shear rate is known as Apparent viscosity. Apparent viscosity is half of the $600 \mathrm{rpm}$ dial value. The apparent viscosity values are dependent on the $600 \mathrm{rpm}$ dial values. Therefore, the highest value at $600 \mathrm{rpm}$ will yield the highest apparent viscosity. Figure 11a shows the comparison between the apparent viscosities 


\section{VISCOSITY (300RPM) = Imported Bentonite}

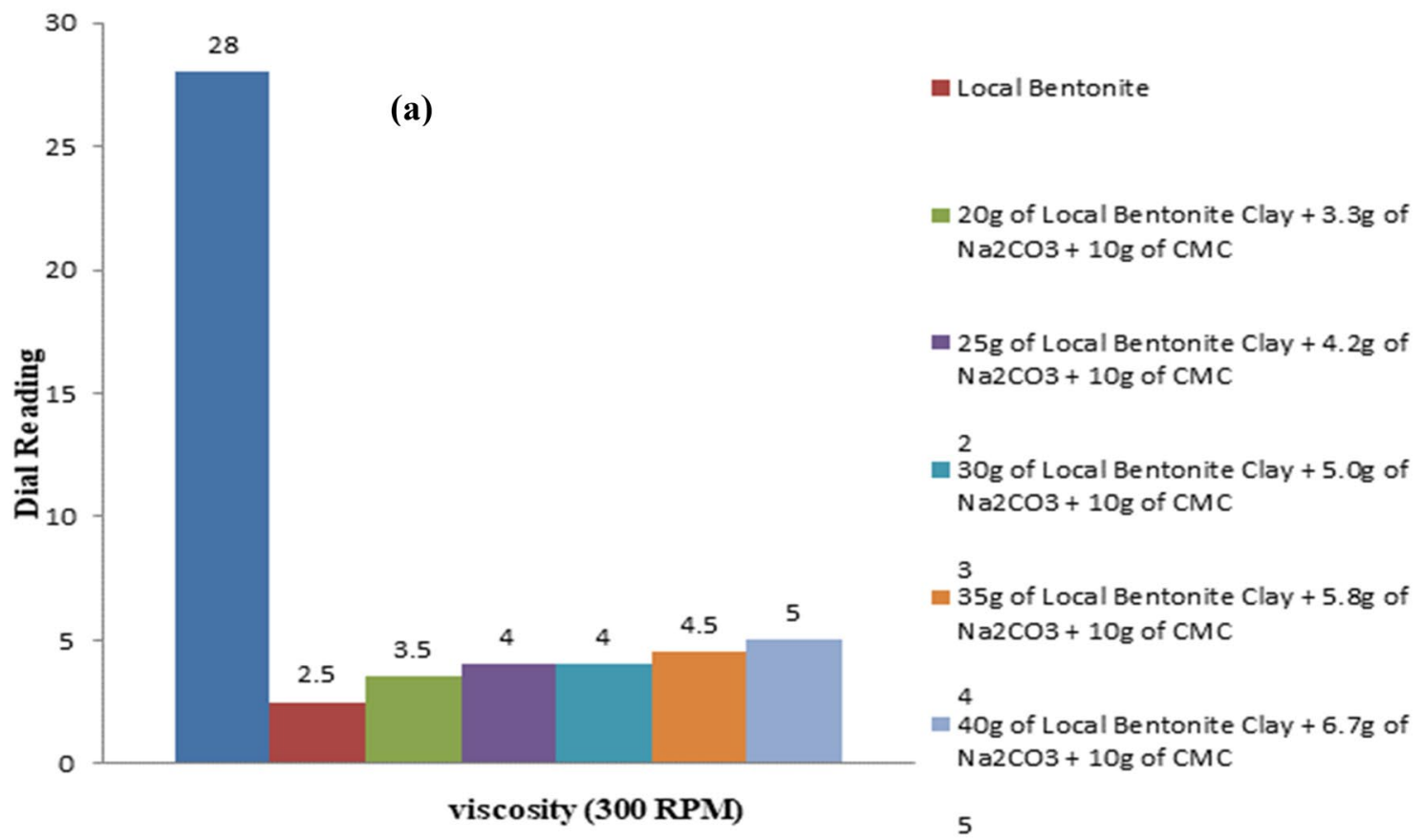

PLASTIC VISCOSITY (CP) = Imported Bentonite

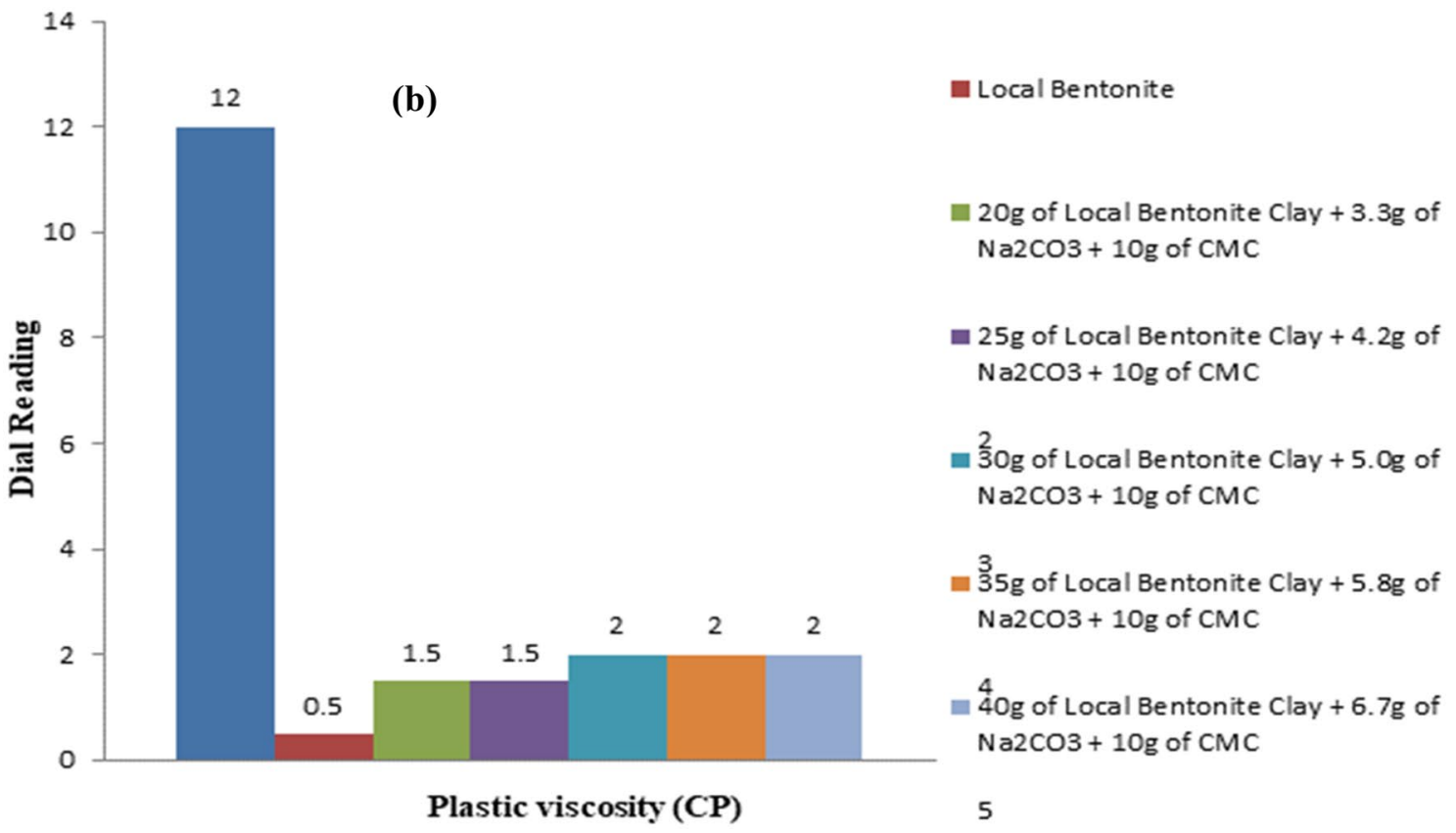

Fig. 10 Histogram showing the Viscosity at 300 RPM (a) and the plastic viscosity (b) of samples

of the standard bentonite, local bentonite, and the five different samples. From the plot, sample five ( $40 \mathrm{~g}$ of Local Bentonite Clay $+6.7 \mathrm{~g}$ of $\mathrm{Na} 2 \mathrm{CO} 3+10 \mathrm{~g}$ of $\mathrm{CMC}$ ) had the highest apparent viscosity value. An increased bentonite concentration led to increased apparent viscosity. Compared with the imported bentonite, the values were low, and there was no significant improvement in apparent viscosity when beneficiated with $\mathrm{Na}_{2} \mathrm{CO}_{3}$ and $\mathrm{CMC}$.

The resistance of the initial fluid flow or the needed stress to move the fluid is known to be the yield point. The yield 

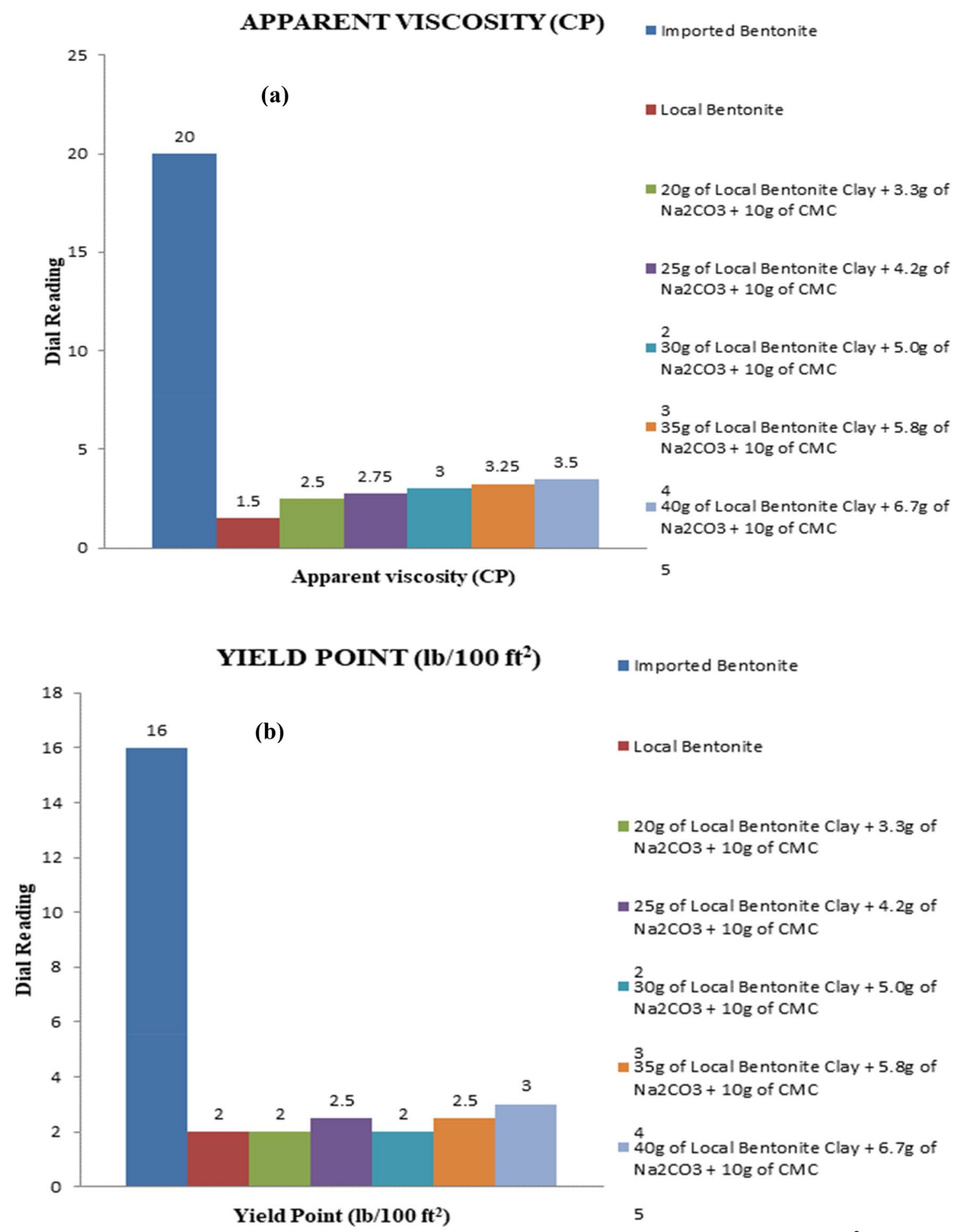

Fig. 11 Histogram showing the Apparent Viscosity (a) and the yield point $\left(\mathrm{lb} . / 100 \mathrm{ft}^{2}\right)(\mathbf{b})$ of samples

point shows the capacity of drilling mud to transport cuttings to the surface. Figure $11 \mathrm{~b}$ shows the comparison between the yield point of the standard bentonite, local bentonite, and the five different samples. From the plot, the different yield point values were obtained subject to the values of viscosity at $300 \mathrm{rpm}$ and plastic viscosity. Since there was a slight improvement in the reading of viscosity at $300 \mathrm{rpm}$ and plastic viscosity, the samples yield point slightly improved when compared with the imported bentonite. 
The capability of the drilling mud to suspend drill cuttings when circulation is ceased is shown by its gel strength. Higher gel strength results in a high tendency of the drilling mud to suspend drill cuttings and vice versa. It is measured once the drilling mud has been at rest for a particular period $(10 \mathrm{~s})$. The gel strength at $10 \mathrm{~s}$ indicates the attractive forces (gelation) strength in a drilling fluid below static conditions.

Figure 12a shows the comparison between the gel strength
GEL STRENGTH (10 SECONDS)

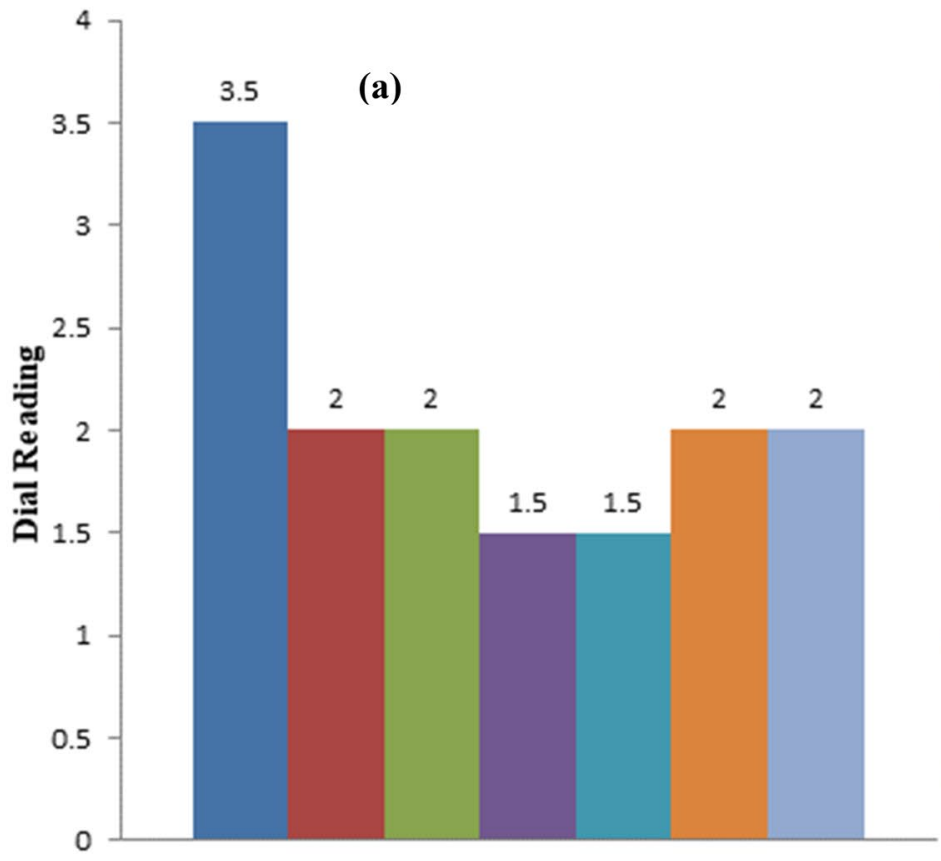

Gel Strength (10 seconds)

FLUID LOSS (ml)

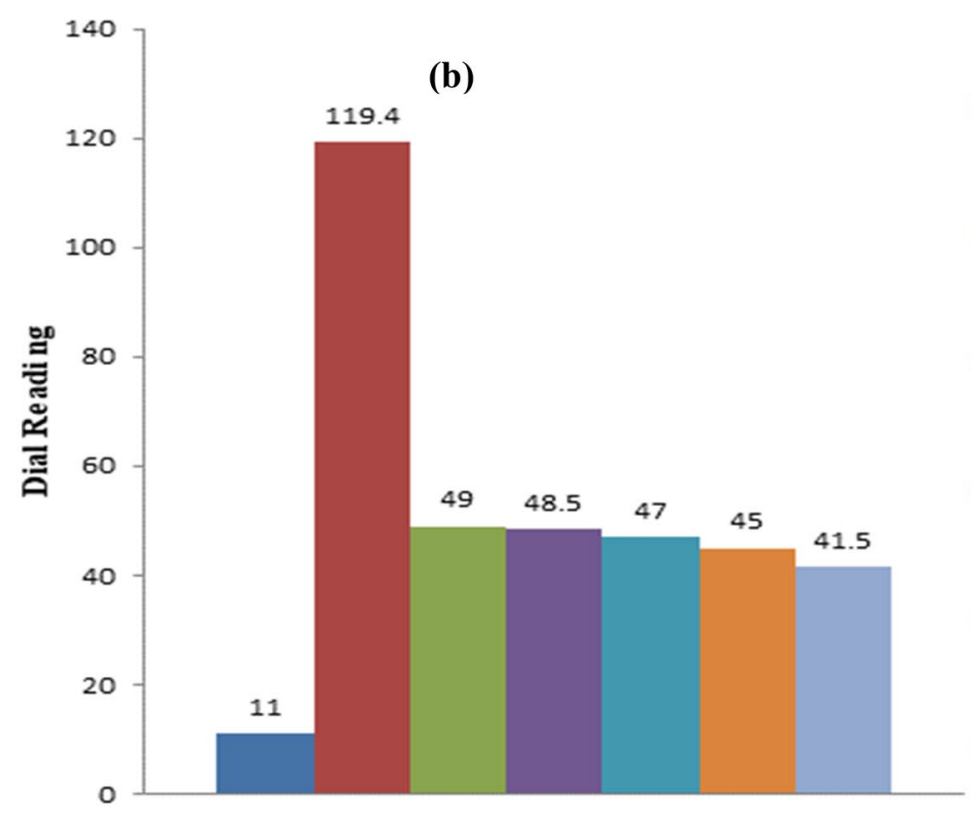

Fluid loss (mI)
- Imported Bentonite

- Local Bentonite

च $20 \mathrm{~g}$ of Local Bentonite Clay $+3.3 \mathrm{~g}$ of $\mathrm{Na} 2 \mathrm{CO} 3+10 \mathrm{~g}$ of $\mathrm{CMC}$

I $25 \mathrm{~g}$ of Local Bentonite Clay $+4.2 \mathrm{~g}$ of $\mathrm{Na} 2 \mathrm{CO} 3+10 \mathrm{~g}$ of $\mathrm{CMC}$

$\because 30 \mathrm{~g}$ of Local Bentonite Clay $+5.0 \mathrm{~g}$ of $\mathrm{Na} 2 \mathrm{CO} 3+10 \mathrm{~g}$ of $\mathrm{CMC}$

$=3^{3} 5 \mathrm{~g}$ of Local Bentonite Clay $+5.8 \mathrm{~g}$ of $\mathrm{Na} 2 \mathrm{CO} 3+10 \mathrm{~g}$ of $\mathrm{CMC}$

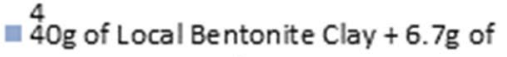
$\mathrm{Na} 2 \mathrm{CO} 3+10 \mathrm{~g}$ of $\mathrm{CMC}$

5

- Imported Bentonite

- Local Bentonite

- $20 \mathrm{~g}$ of Local Bentonite Clay $+3.3 \mathrm{~g}$ of $\mathrm{Na} 2 \mathrm{CO} 3+10 \mathrm{~g}$ of $\mathrm{CMC}$

- $25 \mathrm{~g}$ of Local Bentonite Clay $+4.2 \mathrm{~g}$ of $\mathrm{Na} 2 \mathrm{CO} 3+10 \mathrm{~g}$ of $\mathrm{CMC}$

2

- $30 \mathrm{~g}$ of Local Bentonite Clay $+5.0 \mathrm{~g}$ of $\mathrm{Na} 2 \mathrm{CO} 3+10 \mathrm{~g}$ of $\mathrm{CMC}$

3

- $35 \mathrm{~g}$ of Local Bentonite Clay $+5.8 \mathrm{~g}$ of $\mathrm{Na} 2 \mathrm{CO} 3+10 \mathrm{~g}$ of $\mathrm{CMC}$

4

110 $4 \mathrm{~g}$ of Local Bentonite Clay $+6.7 \mathrm{~g}$ of $\mathrm{Na} 2 \mathrm{CO} 3+10 \mathrm{~g}$ of $\mathrm{CMC}$

5

Fig. 12 Histogram showing the gel strength at $10 \mathrm{~min}$ (a) and the fluid loss (b) of samples 
at $10 \mathrm{~s}$ of the standard bentonite, local bentonite, and the five different samples. The result here indicates that the gel strength of the different samples was constant with beneficiation but declined when treated with $25 \mathrm{~g}$ and $30 \mathrm{~g}$ of local bentonite. This shows that at initial gel strength, there is little stress required for the movement of mud. The values were obtained at a fixed speed of $3 \mathrm{rpm}$ in the viscometer. Generally, the gel strength was low when compared with the standard. Figure $12 \mathrm{~b}$ is a histogram showing the comparison between the fluid loss of the imported bentonite, local bentonite, and the five different samples. The lower the fluid loss, the more suitable the drilling mud and vice versa. It was observed from the plot that the local bentonite exhibited a very high level of fluid loss when compared with the standard bentonite. But after beneficiation with increased volume of the local bentonite, there was a relative improvement in the fluid loss of the treated samples compared to the untreated local bentonite as the filtration loss of the treated samples reduced drastically compared to the untreated bentonite. Sample five ( $40 \mathrm{~g}$ of Local Bentonite Clay $+6.7 \mathrm{~g}$ of $\mathrm{Na}_{2} \mathrm{CO}_{3}+10 \mathrm{~g}$ of $\mathrm{CMC}$ ) showed the greatest improvement in filtration loss. The presence of CMC in the samples helped to reduce filtrate loss as CMC is a fluid loss reducer.

\section{Conclusion}

As the interest for bentonite clays rises, there is a need to improve the rheological properties of Nigerian bentonite to bring it at par with the API international standard. This is necessary to save the country of the huge sums of money lost to the countries of the International oil companies operating in Nigeria in the name of importing drilling mud of superior quality. To maximize the utilization of local bentonite clay for drilling application, beneficiation of calcium bentonite with the use of sodium carbonate, polymer (CMC), and other suitable additives has become important. The results from this research revealed that the beneficiation of local clay with $\mathrm{CMC}$ and the $\mathrm{Na}_{2} \mathrm{CO}_{3}$ through the combination of thermal and mechanical treatment procedures enhanced some of the rheological and flow properties of mud samples. A gradual increase in the concentration of bentonite and $\mathrm{Na}_{2} \mathrm{CO}_{3}$ also influenced the viscosities and properties of the mud samples even though the viscosity values were relatively low. The higher the sodium carbonate concentration, the higher the alkalinity $(\mathrm{pH})$ of the mud sample. The mud sample with the highest bentonite and sodium carbonate concentration $(40 \mathrm{~g}$ of local Bentonite Clay $+6.7 \mathrm{~g}$ of $\mathrm{Na}_{2} \mathrm{CO}_{3}+10 \mathrm{~g}$ of CMC) showed the most improved flow and rheological properties after treatment when compared with the API standard. This implies that with a higher concentration of the additives, the quality of the local bentonite can be upgraded to the desired standard for drilling operations. In order to enhance the viscosity of the local bentonite, further investigation on the use of other chemical additives for the modification of the rheological properties of the mud is encouraged. Other researches could focus on the economic analysis of beneficiating clay using local additives against imported bentonite.

Acknowledgements The authors are grateful to Covenant University for providing financial support.

Open Access This article is licensed under a Creative Commons Attribution 4.0 International License, which permits use, sharing, adaptation, distribution and reproduction in any medium or format, as long as you give appropriate credit to the original author(s) and the source, provide a link to the Creative Commons licence, and indicate if changes were made. The images or other third party material in this article are included in the article's Creative Commons licence, unless indicated otherwise in a credit line to the material. If material is not included in the article's Creative Commons licence and your intended use is not permitted by statutory regulation or exceeds the permitted use, you will need to obtain permission directly from the copyright holder. To view a copy of this licence, visit http://creativecommons.org/licenses/by/4.0/.

\section{References}

Afolabi RO, Orodu OD, Efeovbokhan VE (2017) Properties and application of Nigerian bentonite clay deposits for drilling mud formulation: recent advances and future prospects. Appl Clay Sci 143:39-49

Akintunde A (2012) Experimental determination of the effect of temperature and pressure on the density of water based mud (unpublished project)

Apogu-Nwosu TU, Mohammed-Dabo IA, Ahmed AS, Abubakar G, Alkali AS, Ayilara SI (2011) Studies on the suitability of Ubakala bentonitic clay for oil well drilling mud formulation. Br J Appl Sci Technol 1:152-171

Bleler R, Leuterman AJ, Stark CJ (1993) Pet Technol 45(1):6

Brito BMA, Bastos PM, Gama AJA, Cartaxo JM, Neves GA, Ferreira HC (2018) Effect of carboxymethylcellulose on the rheological and filtration properties of bentonite clay samples determined by experimental planning and statistical analysis. Cerâmica 64:254265. https://doi.org/10.1590/0366-69132018643702332

Dewu BB, Arabic SA, Oladipo MO, Funtua II, Mohammed-Dabo LA, Muhammad AM (2011) Improvement of rheological properties of bentonite clays using sodium carbonate and a synthetic viscosifier. Int Arch Appl Sci Technol 2:43-52

Falode OA, Ehinola OA, Nebeife PC (2007) Evaluation of local bentonite clay as oil well drilling fluids in Nigeria. Appl Sci 39:19-27

Folayan OF, Folayan IM, Folayan JA (2016) Socio-economic characteristics and access of rural farmers to information and communication technologies among Ifedore Local Government Area of Ondo State, Nigeria. Int J Inf Technol Bus Manag 54:1-16

Hosterman JW, Patterson SH (1992) Bentonite and Fuller's earth resources of the United States. Geological Survey Professional Paper, 1522

Hughes TL, Jones TGJ (1990) Chemical composition of CMC and its relationship to the rheology and fluid loss of drilling fluids. In: SPE Paper No. 20000, IADC/SPE Drilling Conference, Houston, Texas, (2), pp 733

Lummus JC, Azar JJ (1986) Drilling fluids optimization-A practical field approach. Pennwell Publishing Company, Tulsa

Magzoub MI, Nasser MS, Hussein IA, Benamor A, Onaizi SA, Slutan A, Mahmoud E (2017) Effects of sodium carbonate addition, heat

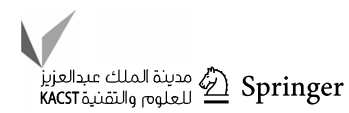


and agitation on swelling rheological behaviour of Ca-bentonite colloidal dispersion. Appl Clay Sci 147:176-183

Olubayode SA, Awokola OS, Dare EO, Olateju OT (2016) Suitability of selected Nigeria clay deposit for production of clay based ceramic water filters. Am Chem Sci J 12(3):1-7

Omole S, James O, Falode AO, Malomo S, Oyedeji OA (2013) Investigation into the rheological and filtration properties of drilling mud and formulated with clays from Northern Nigeria. J Pet Gas Eng 4(1):1-13
Temitope DTO, Opeyemi O (2012) Hydro-geochemical evaluation of groundwater quality in Akoko North West local government area of Ondo State, Nigeria. Revista Ambiente Água Interdiscip J Appl Sci 7:1

Publisher's Note Springer Nature remains neutral with regard to jurisdictional claims in published maps and institutional affiliations. 